\title{
SENI LUKIS BALI DARI PERSPEKTIF MODERNISASI
}

\author{
I Dewa Putu Merta \\ Jurusan Pedalangan, Fakultas Seni Pertunjukan, \\ Institut Seni Indonesia Denpasar, Indonesia
}

\begin{abstract}
One of the strategic attitudes toward development, in order to increase its improvement by arrangement of comprehensive planning, by considering potency as multi sector development concept is the development of art that is taken for consideration. The development of art in Bali nowadays is closely related to the historic movement of Indonesian art, pioneering era Raden Saleh (1807-1880), Hindia Jelita era (1908-1937), and Pita Maha era (1930s). In the Pita Maha era, there occurred a combinatioan between the modern west esthetic and classical Bali esthetic that based on Hindu religion. The modern esthetic was brought to Bali by western artist R. Bonnet and W. Spiese, merging with the classical esthetic which bearing aperiod of art in Bali that is known as Seni Lukis Bali Modern (Bali Modern Art Painting) The period is also the beginning of Modern Art in Bali. Academic movement in the field of art exist in 1950 is an attitude toward renewal expansion within expression. During the orde baru government in 1966, various styles of modern art come into elaboration, moreover by the graduations of many academic artists.
\end{abstract}

Keywords: Seni lukis Bali and modernisasi

Salah satu kebijakan strategis untuk mempercepat pembangunan dengan menyusun suatu perencanaan yang terpadu dan konprehensif dengan melibatkan seluruh unsur pelaku pembangunan dan mempertimbangkan potensi yang ada sehingga terwujud pembangunan yang multi sektor. Salah satunya pembangunan di bidang seni budaya, termasuk didalamnya adalah seni rupa.

Seni Rupa yang berkembang ditengah masyarakat Bali masa ini, tidak terlepas dari perjalanan seni rupa Indonesia. Seni rupa modern hadir dalam masyarakat Indonesia sekarang, sesungguhnya telah dimulai sejak masa perintisan Raden Saleh (1807-1880) yang melukiskan sesuatu dengan wujud kehadirannya bercorak realistis. R. Saleh sebagai pelopor seni rupa Indonesia yang pernah belajar seni lukis di Eropa pertama kali mengembangkan teknik melukis modern di Indonesia (Kusnadi, 1990199:156). 
Perkembangan selanjutnya berselang setengah abad setelah R. Saleh meninggal baru disusul masa Hindia Jelita (Hindie Molek) tahun 1908-1937. Para seniman memandang gejala yang ada disekelilingnya dari sudut yang indah, molek, cantik dan permai, seperti gunung, laut, sawah, ladang, kampung, sungai, fauna dan flora, dan manusia terutama gadis-gadis yang cantik (Ibid. p. 60). Pelukis yang ada masa itu terbagi dua: yaitu kelompok pelukis peribumi dan kelompok pelukis asing yang digandeng oleh penjajah kolonial Belanda. Antara pelukis peribumi dengan pelukis asing sama-sama melukis tentang keindahan alam Indonesia.

Pada masa itu juga Rudolf Bonnet dan Walter Spies datang ke Bali. R. Bonnet dan W. Spies adalah seniman asing yang menaruh perhatian sangat besar terhadap kesenirupaan di Bali. Mereka membentuk perkumpulan yang melibatkan seniman, masyarakat, pemuka desa, dan budayawan melalui pendekatan dan musyawarah dengan berbagai kalangan terutama pihak penguasa Puri Ubud, akhirnya perkumpulan terbentuk pada tahun 1930-an dengan nama "Pita Maha" (Ibid. p. 255). "Pita" artinya luhur dan "Maha" artinya agung, jadi Pita Maha berarti ikatan seniman yang "luhur dan agung. Maksud dan tujuannya adalah untuk memajukan dan mengembangkan nilainilai luhur hasil karya seni dan mengangkat kesejahtraan para senimannya. Pita Maha menjadi wadah para seniman Bali untuk mengembangkan kreativitasnya. Perpaduan estetika modern Barat dengan estetika klasik Bali yang berlandaskan ajaran agama Hindu. Estetika modern dibawa oleh seniman Barat R. Bonnet dan W. Speis bercampur dengan estetika klasik yang dibawa para seniman Bali. Perpaduan dua estetika ini melahirkan mazab baru dalam kesenirupaan di Bali yang disebut Seni Lukis Bali Modern (Murdana, 2001:4).Gaya ini memperhatikan anatomi realistis untuk mengungkapkan kehidupan sehari-hari masyarakat tanpa meninggalkan ciri seni lukis tradisional Bali. Masa ini merupakan tonggak awal pertumbuhan seni rupa modern di Bali ditandai dengan perubahan tema, corak, kebebasan ekspresi, dan bersifat sekuler.

Seputar tahun 1950-an muncul gerakan akademis dalam seni rupa. Hal ini muncul dari aspirasi dan pemikiran para angkatan muda yang ingin penyegaran dalam bentuk karya seni. Pemikiran dan aspirasi tersebut melahir gagasan untuk mendirikan sekolah-sekolah seni. Tahun 1950 lahirkan beberapa sekolah tinggi seni di Indonesia seperti seni rupa di ITB, ASRI Yogyakarta, dan selanjutnya disusul oleh seni rupa di Denpasar, IKJ yang ikut memberikan andil dalam pertumbuhan seni rupa modern di Bali. Konsepsi kesenirupaan mulai dengan jelas dirumuskan secara verbal dalam bentuk buku-buku yang tertulis pada katalog.

Perjalanan seni rupa tidak berjalan mulus walaupun negara Indonesia sudah merdeka. Pada tahun 1965 saat pemerintahan orda lama kegiatan kreativitas seniman sempat terpecah dan mandeg. Seniman tidak masih 
konsentrasi pada kreativitas seni untuk kepribadian, tapi perhatian seniman terbagi untuk kepentingan politik yang sedang bergolak.

Pemerintahan orde baru tahun 1966, dengan kebijakan program pembangunan dalam berbagai sektor, maka seniman Indonesia mulai mendapatkan kebebasan untuk kreativitas. Termasuk pertumbuhan seni rupa Bali juga bangkit lebih-lebih didukung oleh kebijakan program pemerintah, daerah Bali dicanangkan sebagai daerah pariwisata di kawasan Indonesia bagian timur. Sejalan dengan program tersebut pemilik modal mulai menanamkan modalnya di Bali untuk mendukung pembangunan sektor pariwisata. Para pemilik modal juga menanamkan modalnya dalam bidang seni, sehingga muncul art shop dan gallery untuk menampung hasil kreativitas para perupa. Berbagai aliran dalam seni rupa modern berkembang, lebih-lebih dengan banyaknya lahir para perupa-perupa jebolan akademis menambah semaraknya modernisasi seni rupa. Melihat dari paparan diatas, dalam pembahasannya akan menekankan pada: kapan terjadi modernisasi seni lukis Bali dan bagaimana bentuk-bentuk karya seni lukis Bali setelah terjadi modernisasi tersebut.

\section{MODERNISASI SENI LUKIS PITA MAHA}

Pada tahun 1930-an merupakan awal modernisasi seni rupa di Bali. Yang mana sebelumnya berkembang seni lukis klasik yang berpusat di daerah Kamasan Klungkung. Seni lukis ini berbentuk wayang dengan mengambil tema secara umum dari cerita Mahabrata dan Ramayana. Fungsinya untuk menghias tempat suci atau pura dan juga sebagai sarana upacara seperti ulon (hiasan dinding), bendera (kober), umbul-umbul dan lain-lain.

Kemudian pada masa itu Rudolf Bonnet dan Walter Spies datang ke Bali. Rudolf Bonnet dan Walter Spies adalah seniman asing yang menaruh perhatian sangat besar terhadap bentuk perkembangan kesenirupaan di Bali. Salah satu cara mereka dengan membentuk perkumpulan yang melibatkan seniman, masyarakat, pemuka desa, dan budayawan. Setelah mengadakan pendekatan dan musyawarah dengan berbagai kalangan terutama pihak penguasa Puri Ubud, akhirnya perkumpulan bisa terbentuk pada tahun 1930an yang kemudian diberi nama "Pita Maha".

Maksud dan tujuannya adalah untuk memajukan dan mengembangkan nilai-nilai luhur hasil karya seni dan mengangkat kesejahtraan para senimannya. Pita Maha menjadi wadah para seniman Bali untuk mengembangkan kreativitasnya. Wadah ini sebagai tempat berinteraksi antara perupa Bali dengan perupa asing sehingga terjadilah percampuran dua unsur budaya yang berbeda.

Koentjaraningrat menjelaskan, terjadinya percampuran dua unsur kebudayan tertentu dihadapkan dengan unsur-unsur kebudayaan asing, 
sehingga lambat laun diterima dan diolah kedalam kebudayaan sendiri tanpa menyebabkan hilangnya kepribadian kebudayaan itu sendiri (Koentjaraningrat, 1990:248).

Perpaduan antara estetika modern arah Barat dengan estetika klasik Bali yang berlandaskan ajaran agama Hindu. Estetika modern dibawa oleh seniman Barat R. Bonnet dan W. Speise bercampur dengan estetika klasik yang dibawa oleh para seniman Bali. Perpaduan dua estetika ini melahirkan mazab baru dalam keseni-rupaan di Bali yang disebut Seni Lukis Bali Modern.

Gaya seni lukis ini memperhatikan anatomi realistis untuk mengungkapkan kehidupan sehari-hari masyarakat Bali dalam bentuk gaya baru dalam melukis tanpa meninggalkan ciri seni lukis tradisional Bali. Gaya seni lukis ini merupakan tonggak awal per-tumbuhan seni lukis modern di Bali. Modernisasi seni lukis Bali ditandai dengan perubahan tema, corak, kebebasan ekspresi, dan bersifat sekuler. Seni lukis Bali modern dalam proses perwujudan-nya tetap mempertimbangkan kekuatan lokal sebagai landasan berpijak. Meminjam teori pembangunan, bahwa konsep yang dilaksanakan semesti disesuaikan dengan struktur sosial dan kebudayaan lokal, apa yang dilaksanakan merupakan kebutuhan dari masyarakat tersebut. I Ketut Nehen menjelaskan, bahwa sektor modern akan dapat berkembang dengan baik bila sektor tersebut diadaptasikan dengan struktur sosial dan kebudayaan lokal, termasuk pola pelaksanaan kegiatan religius masyarakat (Nehen, 1994:20). Melihat kenyataan dilapangan, apa yang dilaksanakan oleh R. Bonnet dan W. Speise sangat memperhatikan faktor kekuatan lokal yang dimiliki oleh Bali saat itu. Kekuatan lokal yang terletak pada kekuatan bentuk seni lukis wayang tidak diabaikan, dan dipadukan dengan unsur-unsur seni lukis dan estetika Barat. Hal ini terlihat pada karya seni lukisnya I Gst Ketut Kobot yang tetap melukis dengan tema wayang, namun unsur-unsur realis mulai dipertimbangkan pada masing-masing tokoh yang diwujudkan. Bentuk-bentuk plastisitas anatomi pada tokoh wayang sangat tampak. Perspektif yang diterapkan merupakan perpaduan antara perspektif heirarki dengan perspektif seni lukis modern. I Gusti Ketut Kobot dalam penempatan tokoh pada karyanya tetap mempertimbangkan secara hirarki. Salah satunya tokoh penakawan selalu ditempatkan paling bawah dan tokoh dewa paling atas. Modernisasi seni lukis ini juga telah terjadi pada seni lukis gaya Batuan. Dalam seni lukis gaya Batuan nampak sangat berbeda cara ungkapnya dengan seni lukis gaya ubud, walaupun sama-sama berangkat dari seni lukis wayang. Seni lukis gaya Batuan tampak lebih rumit dan dalam sebuah karya dilukiskan berbagai bentuk kegiatan kehidupan sosial masyarakat yang mencerminkan kekinian. Seperti yang terdapat pada karya seni lukis I Rajin, disana diungkapkan seorang touris asing sedang menonton upacara ngaben sambil membidikkan kameranya pada bade (pengusungan mayat). Selain itu I Rajin pula mempertimbangkan perspektif 
dalam berkarya dengan membedakan bentuk obyek yang jauh dan dekat. Perspektif yang paling kentara terlihat pada latar belakang karyanya. Warna yang jauh diungkapkan dengan lebih ringan dan yang dekat lebih gelap. Obyek yang dekat diungkapkan lebih besar sedangkan yang jauh dibuat lebih kecil dan agak kabur. Terkait dengan perspektif, pada karyanya almarhum A.A Gde Sobrat yang berjudul "Pasar Tradisional Bali", beliau menampilkan dua tokoh laki perempuan diungkapkan bentuknya paling besar didepan dan ditonjolkan sebagai pokus dalam karya tersebut, sedangkan bentuk-bentuk manusia dalam pasar yang lain sebagai latar belakang dibuat lebih kecil dan agak kabur. Pada seni lukis Sobrat terlihat terjadi perpaduan antara estetika klasik dengan modern Barat yang dibawa oleh R. Bonnet dan W. Spiece. Penerapan plastisitas anatomi pada karyanya tanpa meninggalkan bentuk-bentuk tradisi yang dimiliki sebelumnya. Gaya seni lukis ini tetap berkembang di wilayahnya masing-masing sampai saat ini, walaupun di luar itu telah ber-munculan seni lukis modern.

\section{Modernisasi Seni lukis Modern Figuratif}

Seputar tahun 1950-an gerakan akademis dalam seni rupa muncul. Gerakan akademis ini bukan berarti seniman-seniman jebolan akademis saja, namun juga para seniman yang memiliki pemikiran sistimatis dalam proses berkarya. Modernisasi dalam bidang kesenian merupakan cerminan dalam usaha untuk pembaharuan, mencari kemungkinan-kemungkinan baru dalam penjelajahan melalui ekspresi. Hal ini muncul dari aspirasi dan pemikiran para angkatan muda yang ingin penyegaran dalam bentuk karya seni. Dalam teori modernisasi dijelaskan, bahwa cara pandang (visi) yang menjadi modus utama analisisnya kepada faktor manusia dalam masyarakat. Modernisasi menjadi semacam komoditi dikalangan masyarakat yang menempatkan faktor mentalitas perubahan. Maka modernisasi tidak lepas dari keberadaan ilmu pengetahuan dan teknologi (Salim, 2002:67).

Terkait dengan teori modernisasi tersebut, pemikiran dan aspirasi lahir dengan gagasan untuk mendirikan sekolah-sekolah seni. Dengan munculnya gagasan penyegaran tersebut lahir beberapa sekolah tinggi seni di Indonesia. Seperti seni rupa di Bandung lahir Balai Pendidikan Guru Gambar, masuk Fakultas Teknik Universitas Indonesia, yang kemudian tahun 1950 menjadi salah satu bagian (jurusan) pada Institut Teknologi Bandung. Di Yogyakarta lahir "Akademi Seni Rupa Indonesia" (ASRI), yang sebelumnya merupakan kursus Guru Menggambar. Kemudian sewaktu ASRI diresmikan pada tahun 1950 lebur menjadi Jurusan Guru Gambar ASRI Yogyakarta (Kartika, 2004:157-158).

Selanjutnya disusul oleh Jurusan Seni Rupa Fakultas Teknik Universitas Udayana Denpasar yang ikut memberikan andil dalam pertumbuhan seni rupa modern di Bali. Kesadaran ilmiah tercermin dalam proses penciptaan karya seninya. Konsepsi kesenirupaan mulai dengan jelas 
dirumuskan secara verbal dalam bentuk buku-buku yang tertulis pada katalog. Dari sini pula memperkuat lahirnya pemikiran-pemikiran ilmiah dibidang seni lukis. Konsep-konsep seni lukis modern makin semarak dikembangkan yang awali dengan lahirnya seni lukis modern figuratif yang masih tetap berkembang dan dilanjutkan oleh para pelukis-pelukis muda saat ini.

Pelukis Dewa Nyoman Batuan yang memiliki latar belakang seni lukis tradisi mengekspresikannya dalam gaya modern dekoratif yang tetap menampilkan figur sebagai wujud ekspresi pada karyanya yang berjudul "Buta ya-Dewa ya", adalah kekuatan atau energi dan kesucian yang selalu ada, tidak bisa terpisahkan bagaikan pisau bermata dua. "Buta ya-Dewa ya" diwujudkan dengan mengkomposisikan satu buah lingkaran ditengah sebagai pusat dan dikelilingi oleh delapan lingkaran opal di penjuru mata angin. Warna lingkaran di sesuai dengan warna pengider Bhuana lengkap dengan simbol sastra dan senjatanya. Warna-warna pengider Bhuana yang dituangkan dalam karyanya merupakan abstraksi dari simbol kekuatan keseimbangan dunia (kosmos). Seni lukis modern figuratif ini berjalan sampai sekarang seiring dengan munculnya konsep seni lukis abstrak murni yang benar-benar meninggalkan bentuk atau bebas tanpa terikat lagi oleh bentuk.

\section{Modernisasi Seni lukis Abstrak}

Setalah pemerintahan orde baru tahun 1966, Seiring dengan kebijakan pencanangan program pembangunan pemerintah Indonesia dalam berbagai sektor, masa ini para seniman mulai mendapatkan kebebasan untuk berkreativitas. Termasuk pertumbuhan seni rupa Bali juga bangkit lebihlebih didukung oleh kebijakan program pemerintah, daerah Bali yang mencanangkan sebagai daerah pariwisata di kawasan Indonesia bagian timur. Sejalan dengan program pembangunan Bali sebagai daerah pariwisata, maka para pemilik modal mulai menanamkan modalnya di daerah Bali untuk mendukung pembangunan sektor pariwisata.

Para pemilik modal juga menanamkan modalnya dalam bidang seni, sehingga muncul bisnis dibidang seni rupa seperti art shop dan gallery di Bali yang menampung hasil kreativitas para perupa. Art shop dan gallery berkembang dan bermunculan bagaikan jamur di musim hujan. Modernisasi dan pembangunan pertumbuhan ekonomi dibangun diatas landasan kapitalisme. Weber menjelaskan, semangat untuk bergerak dalam kapitalisme modern harus memiliki dorongan ekonomi yang lebih kuat. Dalam perwujudannya harus memiliki gagasan-gagasan mengenai kehidupan ekonomi yang rasionalistis. Rasionalisme digunakan untuk menggambarkan suatu sistem ekonomi yang tidak didasarkan pada kebiasaan dan tradisi namun dengan penyesuaian sarana-sarana ekonomi 
yang sistimatis dan cermat menuju pencapaian dari tujuan dalam rangka memperoleh profit (Weber, 2001:7-8).

Terkait dengan hal itu, untuk mencapai pertumbuhan ekonomi melalui modernisasi dibidang seni rupa, hal-hal yang bersifat tradisi tidak mesti ditinggalkan, apalagi kekuatan seni rupa di Bali pada tradisi. Nilai-nilai tradisi ini justru perlu dikembangkan sebagai pondasi seni lukis modern di Bali. Potensi ini dikembangkan untuk mendukung pertumbuhan ekonomi kita. Seperti yang dijelaskan oleh Weber diatas memang ada benarnya. Apabila ingin mencapai kemajuan kehidupan ekonomi, semangat pergerakan modern mesti memiliki dorongan ekonomi yang lebih kuat, memiliki gagasan-gagasan kehidupan ekonomi yang rasionalistis, untuk menggambarkan sistem ekonomi dengan penyesuaian sarana-sarana ekonomi yang sistimatis dan cermat. Namun faktor-faktor yang bersifat tradisi tidak perlu dilupakan atau jangan dipandang sebagai penghambat. Karena tidak semua hal-hal yang bersifat tradisi di suatu negara atau wilayah belum tentu sebagai faktor penghambat ekonomi. Bahkan hal tersebut bisa dimanfaatkan sebagai kekuatan pendorong. Dan tidak semua negara akan dapat mengikuti pergerakan kapitalis modern yang menginginkan perubahan cepat. A. Comte menggambarkan, masyarakat akan berkembang dari masyarakat sederhana (primitif) menuju masyarakat modern (complex) dan memerlukan proses waktu jangka panjang (Fakih, 2000:48)

Hal-hal yang bersifat tradisi dalam seni rupa Bali justru menjadi kekuatan lokal dalam pengembangan seni lukis di Bali, walaupun akan dikembangkan ke dalam seni lukis abstrak. Di dalam ajaran agama Hindu di Bali ada yang dikenal dengan konsep " $r w a$ bhineda" artinya dua hal yang berbeda, seperti hitam-putih, naik-turun, laki-perempuan, ibu-bapak atau lingga-yoni, kaja-kelod (utara-selatan). Apabila dikaitkan dengan konsep minimalis seni lukis abstrak di Barat, rwa bhineda ini merupakan konsep minimalis lokal yang bersifat universal. Wayan Karja menjelaskan dalam penelitiannya, posisi dualisme, falsafah rwabinedha sebagai falsafah lokal Bali disimbolkan dengan hitam-putih, garis vertical-horizontal, gelap-terang, warna panas-warna dingin (Karja, 2003:76). Spirit falsafah rwabinedha dituangkan dalam seni lukis abstrak, diantaranya dapat dilihat pada karyanya I Wayan Sika dengan judul " Poleng", nilai-nilai rwabinedha tersebut diwujudkan dengan kombinasi warna hitam dan putih.

Dengan kemajuan pendidikan dan intelektual akan dapat mendorong lahirnya perupa-perupa muda akademis menambah semaraknya modernisasi seni lukis, dapat mendorong ber-kembangnya berbagai aliran dalam seni lukis modern di tanah air. Di balik semaraknya pertumbuhan dan modernisasi seni lukis di Bali, para perupa tidak berdaya untuk menghadapi kekuatan dan jeratan para pemilik modal (art shop, dan gallery) yang malakukan bisnisnya dibidang seni rupa. Dominasi para pemilik modal terhadap seniman atau pelaku seni sangat menonjol. Hal ini banyak terjadi 
dilapangan, namun masih samar-samar kelihatan dari permukaan bahkan seperti tidak ada. Para pemilik modal lebih banyak menekankan pada keuntungan yang besar terhadap per-usahaannya. Ketimpangan ekonomi terjadi antara seniman dengan pemilik modal. Nilai kreativitas seniman dengan nilai ekonomi yang diterima tidak seimbang. Kesenjangan terjadi bukan saja pada tataran ekonomi, kesenjangan yang muncul pada tingkat perubahan sosial di masyarakat. Konsep pembangunan selalu bergandengan secara serasi dengan konsep modernisasi. Pimikiran modernisasi memang penekanannya adalah pada kemajuan ekonomi yang orientasinya metrialis.

Dalam sistem kapitalis yang menjadi ideologinya adalah keuntungan yang besar. Menurut Marx, implikasi dari konsep Historical Matrialism adalah melihat economic structure sebagai awal dari kegiatan manusia. Economic Structure adalah penggerak perubahan yang akan memimpin perubahan termasuk perubahan sosial (Salim, op. cit. p. 30).

Implikasi pergerakan perubahan dialami oleh para seniman yang mulai terjerat oleh cengkraman art shop dan gallery sebagai pemegang struktur ekonomi, yang pada ujung-ujungnya akan bisa menurunkan kualitas karya dan semangat kreativitas. Kadang-kadang para seniman hanya berfungsi sebagai pekerja, karena kadang-kadang disain karya yang akan dibuat sudah disediakan oleh pemiliki modal. Selain itu harga karya telah ditentukan sendiri oleh pemiliki modal dengan tidak memberikan kesempatan pada seniman untuk menawarkan harga sesuai dengan kualitas karyanya. Hal ini pula membawa perubahan status sosial yang terjadi dikalangan masyarakat, khususnya masyarakat seniman dengan pemodal. Hubungan yang terjadi disini adalah hubungan dominasi, hubungan kekuasaan antara pemilik modal dengan perupa. Pemodal berperan sebagai pemegang dominasi, pemegang kekuasaan atau menghegomoni, sedangkan perupa selalu dipihak dikuasai dan terdominasi atau terhegomoni.

\section{SIMPULAN}

Dari uraian diatas dapat disimpulkan bahwa, modernisasi seni rupa di Bali telah dimulai sejak tahun 1930-an melalui perpaduan antara estetika Barat dengan estetika klasik Bali yang melahirkan mazab baru disebut dengan seni lukis Bali modern. Mulai saat itu sebagai titik awal pertumbuhan seni rupa modern di Bali, dan kemudian didukung oleh perkambangan ilmu pengetahuan seni rupa dengan banyaknya berdiri sekolah-sekolah tinggi seni yang melahirkan pemikiran ilmiah dan konsepsi seni rupa modern membawa penyegaran dalam kreativitas dengan berbagai gaya dalam seni lukis dari modern figuratif sampai abstrak murni. Disamping itu didukung pula oleh program pembangunan yang mencanangkan Bali sebagai daerah pariwisata Indonesia bangian timur, sehingga banyak menarik minat penanam modal yang dapat memudahkan dalam pemasaran hasil karya seni para seniman. 


\section{DAFTAR RUJUKAN}

Fakih, Manssour. 2000. Menolak Pembangunanisme. Pustaka Pelajar Karja, I Wayan. 2003. Seni Lukis Abstrak Sebuah Transformasi Konsep Kosmologi. Hasil penelitian, Denpasar: STSI Denpasar.

Kartika, Dhasono Sony. 2004. Seni Rupa Modern. Bandung: Rekayasa Sains.

Koentjaraningrat. 1990. Pengantar Ilmu Antropologi. Jakarta: Rineka Cipta.

Kusnadi. 1990-1991. Seni Rupa Indonesia Di Masa Perintisan. Tim KIAS, dalam Perjalanan Seni Rupa Indonesia Dari Zaman Prasejarah Hingga Masa Kini. Panitia Pameran KIAS.

Nehen, I Ketut, Pitana. 1994. Transformasi Ekonomi Bali: Loncatan Dari Masyarakat Primer ke Masyarakat Tersier. I Gde (ED.), dalam Dinamika Masyarakat Dan Kebudayaan Bali. Denpasar: BP.

Salim, Agus. 2002. Perubahan Sosial Sketsa Teori Refleksi Metodologi Kasus Indonesia. Yogyakarta: Tiara Wecana Yogya.

Simon, Roger. 2000. Gagasan-Gagasan Politik Gramsci. Yogyakarta: Pustaka Pelajar.

Weber, Max. 2001. Etika Protestan Dan Semangat Kapitalisme. Jakarta: Pustaka Promethea.

Murdana, I Ketut. 2001. Nilai-Nilai Estetik Seni Lukis Bali Modern, Program Seni Rupa Murni Program Pascasarjana Institut Teknologi Bandung. 